\title{
Visual art teachers' determination of the self sufficiency to use alternative assessment tools
}

\author{
Sehran Dilmaç, Oğuz Dilmaç \\ Faculty of Art and Design, İzmir Katip Çelebi University, Turkey
}

\begin{tabular}{|c|c|}
\hline Article Info & ABSTRACT \\
\hline Article history: & \multirow{8}{*}{$\begin{array}{l}\text { The aim of this study was to examine visual arts teachers' opinions on } \\
\text { determination and evaluation of self-efficacy beliefs concerning using to } \\
\text { alternative assessment tools. In this study 'the survey research model' from } \\
\text { descriptive research was used in which the aim was to determine the opinions } \\
\text { of visual arts teachers about the alternative assessment evaluation. } \\
\text { A descriptive survey model was used as the quantitative research method. } \\
\text { Data was obtained through a Likert scale that is also named as 'Progression } \\
\text { File, Performance Assessment and using the Grading Key Sufficiency Scale } \\
\text { by the Visual Arts Teachers'. The study is conducted with } 123 \text { visual art } \\
\text { teachers in the Turkey in the } 2018-2019 \text { academic years. Progression File, } \\
\text { Performance Assessment and using the Grading Key Sufficiency Scale was } \\
\text { applied to Visual Arts Teachers. It was determined that most of the teachers } \\
\text { found themselves adequate about the evaluation process. }\end{array}$} \\
\hline Received Jan 24, 2020 & \\
\hline Revised Apr 13, 2020 & \\
\hline Accepted May 3, 2020 & \\
\hline Keywords: & \\
\hline Alternative assessment & \\
\hline Assessment & \\
\hline Visual arts education & \\
\hline
\end{tabular}

This is an open access article under the CC BY-SA license.

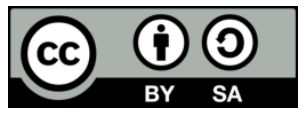

Corresponding Author:

Sehran Dilmaç,

Faculty of Art and Design,

İzmir Katip Çelebi University,

Balatçık Mahallesi Havaalanı Şosesi No:33/2 Balatçık 35620, İzmir, Turkey.

E mail: sehran.dilmac@ikcu.edu.tr

\section{INTRODUCTION}

Visual Arts course is a process in which learners can produce their feelings and thoughts in two or three dimensions by making certain designs with different materials in line with a certain program. In addition, it has a positive effect on the student's perceptual and aesthetic qualities and self-expression skills. To understand this effect, numerical data is needed to determine the level of knowledge and skills of the learners and the realization of the learning objectives determined regarding the learning processes [1]. Alternative assessment approaches, which provide an assessment approach, enable this approach, which includes more appropriate assessment methods for visual arts education. Because the Visual Arts course is primarily a performance-oriented course that aims to observe the development of aesthetics and creativity as well as the cognitive characteristics of the student related to this process $[2,3]$.

The point to be emphasized in the article is that while remembering the content of the subject is easy to test, it is difficult to evaluate critical thinking and creativity. Therefore, alternative assessment tools and methods are needed. Alternative assessment gives teachers a chance to understand their students' weaknesses and strengths in variable situations, as well as evaluating a performance-based and real-life-related process where students are active rather than a result-oriented assessment [4]. Thus, it is thought that the opinions of the teachers about this process will provide information about the applications carried out regarding the evaluation.

In recent years, along with the constructivist approach, an education in which schools aim to develop social skills such as cooperation, self-confidence, and empathic approach by directing students to 
research has been emphasized, and intelligence is addressed in many ways [5]. Visual Arts course has a stimulating, encouraging and developing feature in developing these skills. Studies such as performance tasks and projects that activate high-level mental processes such as critical thinking, problem-solving, creativity, and research are often practiced in the visual arts lesson. It is not possible to measure and evaluate these high-level mental processes in a healthy way with traditional methods. Alternative assessment tools help educators to measure mental and artistic processes in a healthier way and help students organize their thoughts about critical and complex problems, unlike traditional tools. When students give short answers or choose one of the multiple options in traditional tools, they create answers from their perspectives with real tools and present their answers in different ways [6, 7]. While traditional methods generally evaluate memorized information, alternative assessment tools try to reveal students' understanding and success. In this context, alternative assessment tools have an alternative feature for students with different learning styles and provide alternatives for the assessment of these students [8]. In the traditional teaching approach, the effectiveness of evaluating learning is generally carried out with result-oriented exams considering that it is separate from teaching. Therefore, the traditional assessment method is not effective in measuring knowledge and skills. Moreover, traditional assessments are insufficient to measure learning and skills to reflect the success of expected standards, unless they are integrated with performance-based assessments [9, 10].

The evaluation process is limited to traditional tools and methods as mentioned above will not meet this need given the structural feature of the visual arts course. It is not possible to measure creativity with any traditional assessment tool in a visual arts course, one of which is to increase the creative imagination of the student. "Traditional methods are not organized in the form of activities that lead students to research by thinking about them and because they are not allowed to use information, problem-solving; in short, to reconstruct knowledge, students graduate with superficial knowledge they memorize" [11]. Art activities have many features that emphasize individuality and originality. Therefore, alternative assessment tools are needed, which are different from traditional assessment practices, which are more flexible, comprehensive, which can measure different skills and include the process. It is a complex process to understand the effects of art programs on the cognitive and affective development of the student and to measure the levels of artistic creativity together or separately $[12,13]$. The Visual Arts course, it is better to evaluate student studies that do not have a single correct answer, as in other courses, by using several different assessment tools. For this reason, performance evaluation should be used from the alternative assessment approach that measures students' real problem-solving skills by focusing on performance and process [14].

Starting from 1990, the student-centered education approach led to the use of various evaluation methods (performance evaluation, portfolio evaluation, etc.) and tools (rubrics, checklists, attitude scales, scoring instructions) $[15,16]$. These assessment methods and practices help teachers to obtain more accurate results related to the artistic learning process by measuring different dimensions of artistic learning. It is also of great importance that teachers can choose appropriate alternative assessment tools when evaluating their students' artistic production. Instead of a result-oriented assessment, evaluating a process in which students are active, a performance-based and real-life process will provide a more accurate assessment of the achievements.

There are various studies in the literature showing that alternative assessment approaches increase success in different disciplines and different subject areas. Er [17] found that revealed the positive effects of alternative evaluation on success and attitude as a result of his applied research including structured grid and diagnostic branched tree used as an alternative assessment tool. In addition, it has been found that alternative assessment approaches make the lessons enjoyable, understandable and interesting, and this method allows them to understand the lesson more easily and provides permanence in their learning. In Başoğlu [18] it was determined that alternative evaluation had a positive effect on academic success. They concluded that the electronic rubrics used by Manuela and Jesus [19] in the alternative assessment make it easier for students to access resources in teaching, that they are satisfied with their use in both self and peer assessments, and have positive effects on the application process and learning process. In the study conducted by Manuela and Jesus [19], they found that electronic rubrics used in alternative assessment is an assessment that facilitates access to resources in teaching for students, they are satisfied with their use in both self and peer assessments, and have positive effects on the application process and learning process. As a result of the research carried out by Maimouna and Salma [20] to determine the opinions of the teachers about the alternative assessment they carried out, it was concluded that the teachers developed the awareness of the alternative assessment about the learning of the students and that the teachers received the training and support they received regarding the assessment. Research shows that evaluation has more accurate results when tasks have real-life value and students perform real-world tasks [21]. Therefore, alternative assessment plays a major role in increasing students' learning, making them more competent in their fields of study. In the researches carried out, it is seen that teachers lack the knowledge and need training in using and preparing assessment and evaluation tools in the curriculum [22, 23]. This will also affect teachers' self-efficacy levels and educational

Visual art teachers' determination of the self sufficiency to use alternative assessment ... (Sehran Dilmaç) 
environment. According to Mojavezi and Tamiz's [24] research results on the relationship between teacher self-efficacy and motivation of students and its effect on success, a positive relationship was found between teacher self-efficacy and student motivation. Therefore, it can be argued that these and similar studies on teacher self-efficacy are studies that will support the relevant literature.

Measurement and evaluation are important in terms of revealing the effectiveness of the materials, methods, techniques and curriculums used in teaching, understanding the extent of learning, taking the necessary measures for teaching and planning the next stage. Especially in terms of the quality of learning, it helps to see the extent of the gains and the areas where the students have difficulties in learning and the wrong learning. The approach adopted and the methods used in evaluation are also important. The evaluation should be based on an understanding that the product is included in the evaluation as much as in the process. Therefore, at the end of the process, the performance of the student should be evaluated together with the learning product put forward. However, in order to ensure that alternative assessment methods are used by taking these suggestions into consideration, a belief should be established that teachers will be useful. In the formation of such a belief, research should show the contribution of these methods to learning, unlike other methods, and indicate the conditions for maximum utilization. In this study, self-efficacy levels of visual arts teachers related to alternative assessment methods were tried to be determined. Thus, it is thought that it will contribute to educators and researchers by revealing the effectiveness of alternative methods mentioned in the curriculum. Therefore, it can be argued that these studies such as teacher self-efficacy and so on are studies that will support the relevant literature.

\section{METHOD}

This section includes descriptions of the research model, sample, data collection tool, application and techniques used in the analysis of data.

\subsection{Model of the research}

In this research, which was carried out due to the determination of the thoughts related to the evaluation of Visual Arts teachers, a descriptive scanning method was applied. "Self-Efficacy Scale for Using Visual Arts Teachers' Alternative Assessment Tools," which was designed as a Likert-type measurement tool developed by Dilmaç [25], was used to access the data.

\subsection{Participants}

The population of the spring semester of 2018-2019 academic year, this research has been serving in Turkey constitutes 123 visual arts teacher. Information on the quantitative group is given in Table 1. When Table 1 is examined, 51 of the 123 Visual Arts teachers in the quantitative group are women (41\%) and 72 are men $(59 \%) ; 92(74 \%)$ of the visual arts teachers are graduates of the education faculty, $31(26 \%)$ are graduates of the Faculty of Fine Arts, according to the type of faculty type graduated; In terms of professional seniority variable, $52(42 \%)$ of visual arts teachers have 1-5 years of professional seniority, $39(32 \%) 6-10$ years of professional seniority and $32(26 \%)$ of 11 years or more professional seniority. It has been determined to have.

Table 1. Information on visual arts teachers

\begin{tabular}{|c|c|c|c|c|}
\hline Variable & & & $\mathrm{f}$ & $\%$ \\
\hline \multirow{2}{*}{ Gender } & & Woman & 51 & 41 \\
\hline & & Male & 72 & 59 \\
\hline \multicolumn{3}{|c|}{ Total } & 123 & 100 \\
\hline \multirow{2}{*}{ Graduated Faculty } & & Education Faculties & 92 & 74 \\
\hline & & Faculty of Fine Arts & 31 & 26 \\
\hline \multirow{5}{*}{ Professional Experience } & Total & & 123 & 100 \\
\hline & & $1-5$ Years & 52 & 42 \\
\hline & & 6-10 Years & 39 & 32 \\
\hline & & 11 Year and Above & 32 & 26 \\
\hline & Total & & 123 & 100 \\
\hline
\end{tabular}

\subsection{Data collection tools}

"The Self-Efficacy Scale of Using Visual Arts Teachers' Alternative Assessment Tools" developed by Dilmaç [25] was used as the data collection tool of the research. The data collection tool used in the research is introduced in detail below. In this study, it was aimed to determine the self-efficacy beliefs of the visual arts teachers regarding the product selection file and to determine their opinions about 
the evaluation. The size of the research was shaped by evaluating the data obtained through the relevant literature review and expert opinions. Within the scope of the research, "The Self-Efficacy Scale of Using Visual Arts Teachers' Alternative Assessment Tools," prepared by Dilmaç [25], was used to determine the self-efficacy beliefs of the visual arts teachers. Before the questionnaire was developed, a wide-ranging literature review was conducted on the place of visual arts education, what performance evaluation is. In this survey, it is aimed to determine the visual arts teachers' ability to use progress record files, performance evaluation and graded scoring key, and to use the measurement tools and methods. While preparing the questionnaire, the general attitudes and thoughts of the visual arts teachers towards the assessment and evaluation methods existing in the secondary school visual arts course program were collected. By the opinions collected from visual art teachers and researches, a total of 52 items questionnaire was created. Specialist opinions were taken from these items and those who were eligible to take part in the survey were determined. In the survey consisting of 52 items at the beginning, 24 items were determined by removing the items that are not in line with the target and identical with each other and the last point was put in the survey. Created this survey was administered to a teacher in schools about taking necessary permission in Turkey. In the first part of the created questionnaire, the faculties of their visual arts teachers, their term of office. In the second part, to determine the ability of visual arts teachers to apply their progress file, performance evaluation and graded scoring key, Likert type "Completely agree, moderately agree, neither agree nor disagree, Moderately disagree, completely disagree", contains Likert type five-point items. The relevant data have been thoroughly analyzed in the SPSS 13.0 Agree" package program. In the light of the reviews; t-test results for item averages are $p>0.05$ and correlation coefficients $r<.27$ items with 30 items below and 1 item with item-total correlation value below 0.30 were also removed from the pilot scale. The Cronbach Alpha internal reliability coefficient of the questionnaire was determined as 92 .

\subsection{Data analysis}

During the analysis of the data, it was first checked whether the assumptions such as "Data should be intermittent or proportional", which are among the assumptions of the parametric tests, "Data should conform to the normal distribution" and "Group variances should be equal". To determine the normal distribution of the scores obtained from the sample group, Shapiro-Wilk normality test was examined and kurtosis-skewness values were examined and nonparametric tests were decided to be performed since the data were not normally distributed and the frequency values for some variables were less than 30 . Of the tests, it was decided to use the Mann Whitney $U$ test for the comparison of the two groups, and the Kruskal Wallis test for the comparison of more than two groups. Analysis results were tested at $p<0.05$ significance level.

\section{RESULTS AND DISCUSSION}

In this part of the study, the results of the analysis on the self-efficacy levels of the visual arts teachers using alternative assessment tools and the opinions of the visual arts teachers on the evaluation are included.

\subsection{Findings related to the first sub-problem}

Descriptive statistics on visual arts teachers' ability to use progress file, performance evaluation and graded scoring keys are given in Table 2. The descriptive statistics about the self-efficacy items of visual arts teachers using alternative assessment tools are given, Table 2 . When examined, teachers can use the product file effectively in the evaluation $(X=3.78)$, they can easily evaluate the product files $(\bar{X}=3.82)$, and they can select the appropriate criteria in the evaluation of the product files $(X=3.88)$, they have graded scoring key effectively in evaluating product files $(X=3.82)$, they have sufficient information about the product file $(\bar{X}=3.73)$, they can use the product file effectively $(\bar{X}=3.75)$, they do not need measurement and evaluation specialists to prepare the appropriate grade scoring key for the product file $(X=3.17)$, they can assign performance tasks according to the students' gender $(\bar{X}=3.91)$, they can choose their performance tasks per the gain specified in the program $(X=3.88)$, they do not need a measurement and evaluation specialist in evaluating performances $(\overline{\mathrm{X}}=3.81)$, they can use performance evaluation effectively in class/workshop $(\overline{\mathrm{X}}=4.11)$, they can prepare appropriate environments for evaluating students' performance $(\overline{\mathrm{X}}=3.92)$. They stated that they knew $(\overline{\mathrm{X}}=3.10)$. 
Table 2. Descriptive statistics of visual art teachers' self-efficacy scale for using alternative evaluation tools

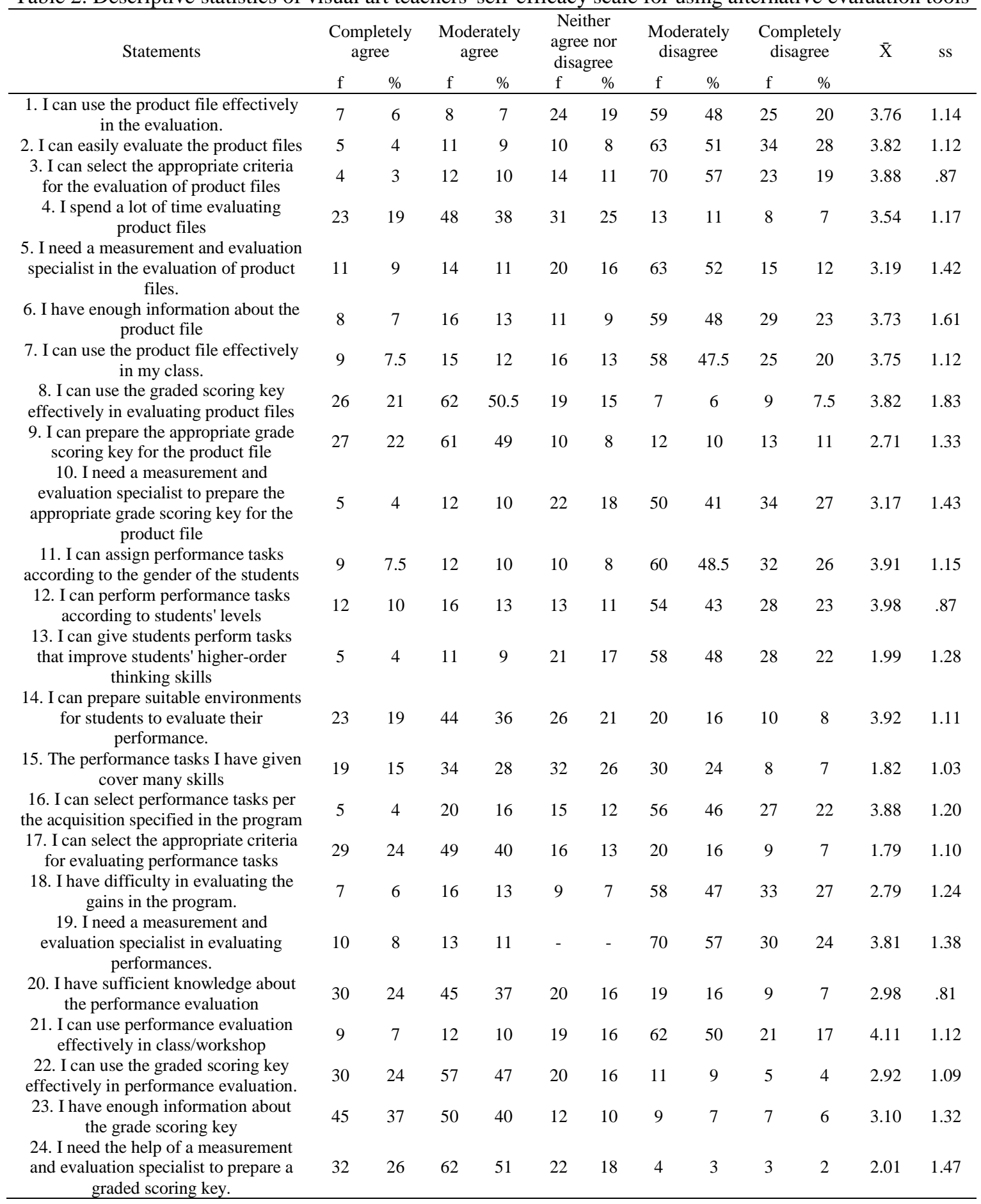

On the other hand, they spend a lot of time during the evaluation of product files $(\overline{\mathrm{X}}=.54)$, students cannot give performance tasks that improve their high-level thinking skills $(\overline{\mathrm{X}}=1.99)$, that their performance tasks do not include many skills $(\overline{\mathrm{X}}=1.82)$, and they do not select appropriate criteria for evaluating performance tasks. $(\bar{X}=1.79)$ expressed. Baker [26] confirms this idea that the teachers stated that they had difficulty because they did not receive education for teaching suitable for alternative assessment and evaluation. In general, in the light of the data obtained at the end of the research, it is seen that the belief and self-efficacy levels of the teachers are high regarding the measurement of student success by using different methods instead of adhering to one method. These results are different from the results of Huff's [27] study, where he examined the teachers' views on the process of creating a portfolio. As a result of the Huff study, 
it was concluded that using teachers' portfolio in both evaluation and professional development tired them mentally and negatively affect their self-efficacy levels. Against this, the results obtained by Duran, Mihladiz and Ballıel [28], Güneş, Dilek, Hoplan, Çelikoğlu and Demir [29] and İzci, Göktaş and Süleyman [30] are similar to this study. According to the research findings in which Kilmen and Kösteroğlu [31] examined the opinions of the teachers about alternative assessment, more than half of the teachers find complementary assessment approaches useful, important, necessary and they think that they give the students the opportunity to evaluate themselves. In these studies, students may have obtained high scores from these techniques, as their perception of competence increased by developing a positive attitude towards alternative assessment. In accordance with the results of this study, in his study where alternative evaluation techniques and classical techniques of Oluk and Ekmekçi [32] compare the activities of measuring student success, he found a significant difference between alternative evaluation techniques and traditional evaluation techniques and revealed that the difference was in favor of alternative techniques. Alternative assessment focuses specifically on evaluating student performance during the teaching process. Therefore, performance evaluations can be considered to have positively affected the results of the research carried out, as there are evaluations that require students to advance knowledge, last learning and related skills to solve realistic, original problems while actively performing complex or important tasks. US and Turkey teacher of alternative assessment tools to research results also support the comparison of views on these results [9]. They stated that especially teachers who work in the USA had difficulties in informing students and using time effectively while using alternative assessment tools. In Oliver [33], it states that the implementation of alternative assessment is labor intensive and time consuming. It requires continuous training and development opportunities that can be costly for educators. Ozan [34] conducted by authentic assessment of academic achievement and influence the opinions of attitudes and teachers for educational measurement research entitled consequences authentic assessment of teachers' academic achievement and attitudes towards educational measurement of candidates to significantly increase and also an important issue in the field of teacher training in Turkey It is determined that there is an approach that can help establish cooperation between theory and practice.

\subsection{Findings related to the second sub-problem}

The results of the Mann Whitney $U$ test on whether the opinions of the visual arts teachers about the progress file, success evaluation and graded scoring keys differ according to the gender variable are given in Table 3. When the results of the Mann Whitney Utest conducted on whether the opinions of the visual arts teachers about using the self-efficacy items of the alternative assessment tools change according to the graduated faculty variable, the table averages of teachers who graduated from the Faculty of Education (63.12) and Fine Arts There is a significant difference between the rank averages of teachers graduated from the Faculty of Education (32.19) $[(\mathrm{U}=634.5, \mathrm{p}<.05]$ and this difference is in favor of the graduates of the Faculty of Education. In the article "I can easily evaluate the product files.", There is a significant difference between the rank averages of teachers graduated from Faculty of Education (64.33) and the rank averages of teachers graduated from Faculty of Fine Arts (48.48) $[(U=612.5, p<.05]$ and this difference There is a significant difference in favor of Faculty of Education graduate teachers between the rank averages (51.12) of the graduates of the Faculty of Fine Arts (42.96) and the average ranges of the graduates of the Faculty of Fine Arts (42.96). = 701.0, $p<.05]$; In the article "I need a measurement and evaluation specialist in the evaluation of product files", there is a significant difference between the average ranks of teachers graduated from Faculty of Education (42.10) and the average ranks of teachers graduated from Faculty of Fine Arts (66.13) [(U = 740.5, p <. 05] and this difference is in favor of the graduates of the Faculty of Fine Arts; in the article "I have sufficient information about the product file." There is a significant difference between the average ranks of the graduates of the Faculty of Education (63.17) and the average ranks of the graduates of the Faculty of Fine Arts (43.64). [ $(U=650.5, p<.05]$ and this difference is in favor of the graduates of the Faculty of Education; There is a significant difference between the rank averages of teachers graduated from Faculty of Education (57.99) and the rank averages of teachers graduated from Faculty of Fine Arts (45.80) in favor of teachers who graduated from Faculty of Fine Arts (" $U=689.0, \mathrm{p}<.05]$; There is a significant difference in the favor of the graduates of the Faculty of Fine Arts between the rank averages of the graduates of the Faculty of Education (35.00) and the average of the graduates of the Faculty of Fine Arts (55.09) in the article "I can assign performance tasks according to the gender of the students." $U=566.0, p<.05]$.

The alternative assessment techniques that emerge in the constructivist approach load the teachers' roles such as organizing, designing and directing [35, 36]. Therefore, it may be due to the fact that the teachers who have been educated in the education faculty have encountered more constructivist approach during the undergraduate education process and applied this in their professional life. The results obtained by Karamustafaoğlu, Çağlak and Meşeci [37] in their research to determine the self-efficacy of the classroom

Visual art teachers' determination of the self sufficiency to use alternative assessment ... (Sehran Dilmaç) 
teachers' assessment and assessment tools support this finding. When the results of their research are analyzed, it is seen that the teachers graduated from education faculties have a higher average compared to other faculty graduates. These results support these findings.

Table 3. Differentiation of visual art teachers' opinions on the scale of competency to use alternative assessment tools by graduated faculty variable

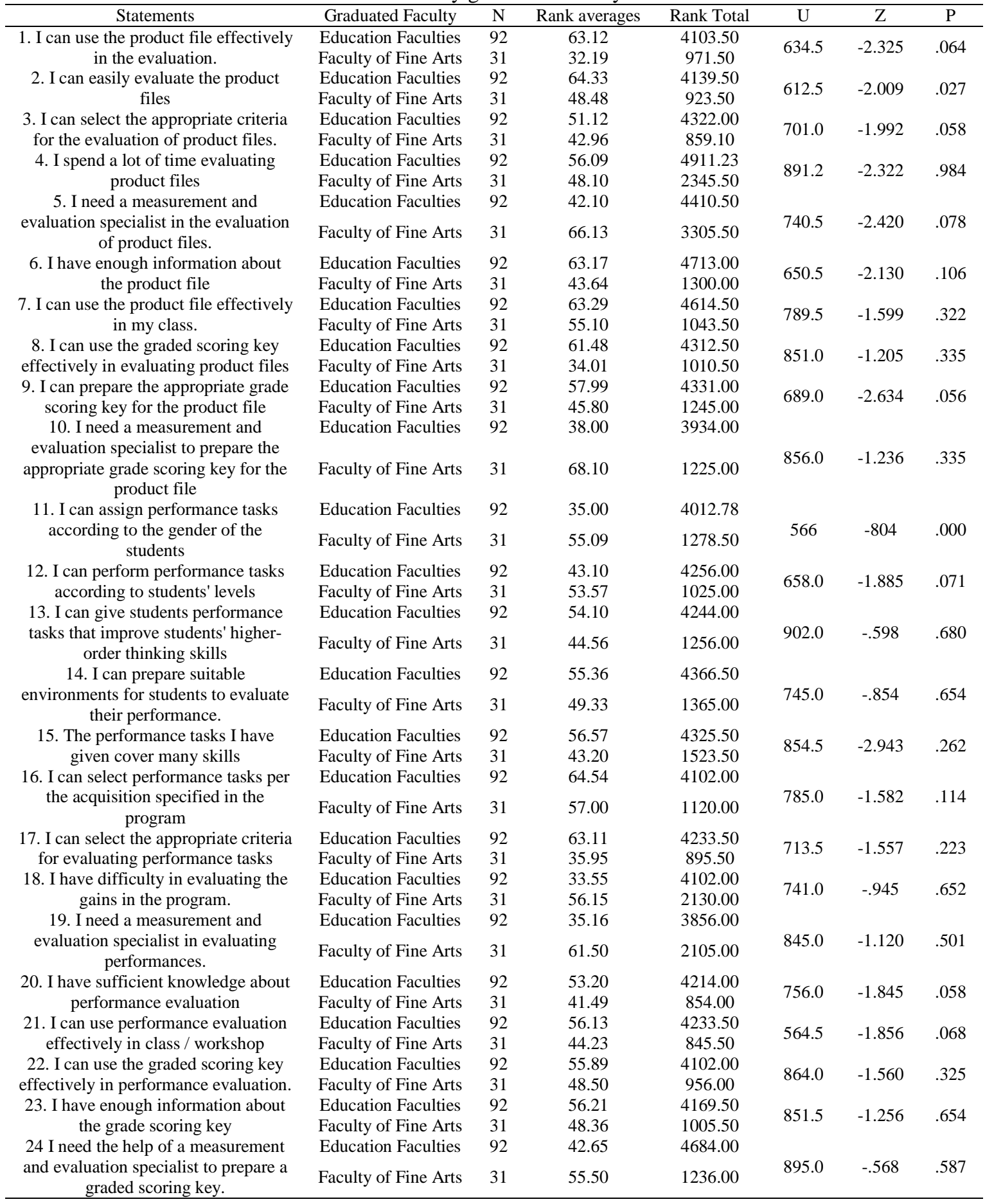

\subsection{Findings related to the third sub-problem}

The results of the Kruskal Wallis Test on whether the opinions of different visual arts teachers with different professional experience differ regarding their development file, performance evaluation and graded scoring keys are presented in Table 4.

Int. J. Eval. \& Res. Educ. Vol. 9, No. 2, June 2020: 292 - 302 
Table 4. Kruskal Wallis test results on items of self-efficacy scale of visual arts teachers with different professional seniority using alternative evaluation tools

\begin{tabular}{|c|c|c|c|c|c|c|c|}
\hline Statements & Professional Experience & $\mathrm{N}$ & Rank averages & $X^{2}$ & $\mathrm{sd}$ & $\mathrm{p}$ & Difference \\
\hline \multirow{3}{*}{$\begin{array}{l}\text { 1. I can use the product file } \\
\text { effectively in the evaluation. }\end{array}$} & $1-5$ Years & 60 & 56.52 & \multirow{3}{*}{1.278} & \multirow{3}{*}{2} & \multirow{3}{*}{.657} & \\
\hline & 6-10 Years & 41 & 41.23 & & & & \\
\hline & 11 Year and Above & 22 & 42.00 & & & & \\
\hline \multirow{3}{*}{$\begin{array}{l}\text { 2. I can easily evaluate the } \\
\text { product files }\end{array}$} & 1-5 Years & 60 & 55.53 & \multirow{3}{*}{.655} & \multirow{3}{*}{2} & \multirow{3}{*}{.897} & \\
\hline & 6-10 Years & 41 & 51.10 & & & & \\
\hline & 11 Year and Above & 22 & 46.00 & & & & \\
\hline \multirow{3}{*}{$\begin{array}{l}\text { 3. I can select the appropriate } \\
\text { criteria for the evaluation of } \\
\text { product files }\end{array}$} & 1-5 Years & 60 & 54.78 & \multirow{3}{*}{2.349} & \multirow{3}{*}{2} & \multirow{3}{*}{.236} & \\
\hline & 6-10 Years & 41 & 40.36 & & & & \\
\hline & 11 Year and Above & 22 & 56.70 & & & & \\
\hline \multirow{3}{*}{$\begin{array}{l}\text { 4. I spend a lot of time } \\
\text { evaluating product files }\end{array}$} & 1-5 Years & 60 & 40.12 & & & & \\
\hline & 6-10 Years & 41 & 55.63 & 2.658 & 2 & .365 & \\
\hline & 11 Year and Above & 22 & 60.63 & & & & \\
\hline 5. I need a measurement and & 1-5 Years & 60 & 44.69 & & & & \\
\hline evaluation specialist in the & 6-10 Years & 41 & 43.75 & 5.120 & 2 & .085 & \\
\hline evaluation of product files. & 11 Year and Above & 22 & 63.40 & & & & \\
\hline 6 I have enough information & 1-5 Years & 60 & 56.79 & & & & \\
\hline 6. I have enough information & 6-10 Years & 41 & 43.18 & 2.364 & 2 & .540 & \\
\hline & 11 Year and Above & 22 & 41.18 & & & & \\
\hline & 1-5 Years & 60 & 53.10 & & & & \\
\hline 7. I can use the product file & 6-10 Years & 41 & 50.50 & .960 & 2 & .699 & \\
\hline effectively in my class. & 11 Year and Above & 22 & 49.53 & & & & \\
\hline 8. I can use the graded scoring & 1-5 Years & 60 & 60.14 & & & & \\
\hline key effectively in evaluating & 6-10 Years & 41 & 45.30 & 5.502 & 2 & .741 & \\
\hline product files & 11 Year and Above & 22 & 43.18 & & & & \\
\hline 9. I can prepare the appropriate & 1-5 Years & 60 & 61.18 & & & & \\
\hline grade scoring key for the & $6-10$ Years & 41 & 55.94 & 4.632 & 2 & .165 & \\
\hline product file & 11 Year and Above & 22 & 41.95 & & & & \\
\hline 10. I need a measurement and & 1-5 Years & 60 & 55.36 & & & & \\
\hline evaluation specialist to prepare & $6-10$ Years & 41 & 59.56 & 2.653 & 2 & .365 & \\
\hline $\begin{array}{l}\text { the appropriate grade scoring } \\
\text { key for the product file }\end{array}$ & 11 Year and Above & 22 & 44.56 & & & & \\
\hline 11. I can assign performance & 1-5 Years & 60 & 56.12 & & & & \\
\hline tasks according to the gender & 6-10 Years & 41 & 47.89 & .974 & 2 & .489 & \\
\hline of the students & 11 Year and Above & 22 & 51.50 & & & & \\
\hline & 1-5 Years & 60 & 43.47 & & & & Over 11 \\
\hline $\begin{array}{l}\text { 12. I can perform performance } \\
\text { tasks according to students' }\end{array}$ & $6-10$ Years & 41 & 53.10 & 9.235 & 2 & .007 & \\
\hline levels & 11 Year and Above & 22 & 61.47 & & & & $\begin{array}{c}\text { and 6-10 } \\
\text { Years }\end{array}$ \\
\hline 13. I can give students & $1-5$ Years & 60 & 4126 & & & & Over 11 \\
\hline performance tasks that improve & & & 41.20 & & & & Years $>1-$ \\
\hline students' higher-order thinking & 6-10 Years & 41 & 47.14 & 9.412 & 2 & .005 & 5 Years \\
\hline skills & 11 Year and Above & 22 & 59.25 & & & & $\begin{array}{l}\text { and 6-10 } \\
\text { Years }\end{array}$ \\
\hline 14. I can prepare suitable & 1-5 Years & 60 & 56.14 & & & & \\
\hline environments for students to & 6-10 Years & 41 & 50.75 & 1.742 & 2 & .568 & \\
\hline evaluate their performance. & 11 Year and Above & 22 & 45.44 & & & & \\
\hline & 1-5 Years & 60 & 59.14 & & & & 1-5 Years \\
\hline 15. The performance tasks I & 6-10 Years & 41 & 41.36 & 9.815 & 2 & .009 & $>11$ years \\
\hline have given cover many skills & 11 Year and Above & 22 & 46.10 & & & & and above \\
\hline 16. I can select performance & 1-5 Years & 60 & 54.66 & & & & \\
\hline tasks per the acquisition & 6-10 Years & 41 & 51.84 & 5.244 & 2 & 4.852 & \\
\hline specified in the program & 11 Year and Above & 22 & 48.56 & & & & \\
\hline 17. I can select the appropriate & 1-5 Years & 60 & 59.25 & & & & \\
\hline criteria for evaluating & 6-10 Years & 41 & 51.15 & 5.125 & 2 & .097 & \\
\hline performance tasks & 11 Year and Above & 22 & 46.10 & & & & \\
\hline 18. I have difficulty in & 1-5 Years & 60 & 44.13 & & & & \\
\hline evaluating the gains in the & 6-10 Years & 41 & 51.20 & .962 & 2 & .741 & \\
\hline program. & 11 Year and Above & 22 & 56.30 & & & & \\
\hline 19. I need a measurement and & 1-5 Years & 60 & 50.18 & & & & \\
\hline evaluation specialist in & 6-10 Years & 41 & 61.14 & 3.365 & 2 & .568 & \\
\hline evaluating performances. & 11 Year and Above & 22 & 45.94 & & & & \\
\hline & $1-5$ Years & 60 & 56.18 & & & & \\
\hline 20. I have sumicient Knowledge & 6-10 Years & 41 & 50.46 & 1.125 & 2 & .658 & \\
\hline & 11 Year and Above & 22 & 43.75 & & & & \\
\hline 21. I can use performance & 1-5 Years & 60 & 61.56 & & & & 1-5 Years \\
\hline evaluation effectively in class / & 6-10 Years & 41 & 47.15 & 9.452 & 2 & .008 & $>11$ years \\
\hline workshop & 11 Year and Above & 22 & 41.16 & & & & and above \\
\hline
\end{tabular}


Table 4. Kruskal Wallis test results on items of self-efficacy scale of visual arts teachers with different professional seniority using alternative evaluation tools (continued)

\begin{tabular}{|c|c|c|c|c|c|c|c|}
\hline Statements & Professional Experience & $\mathrm{N}$ & Rank averages & $X 2$ & sd & $\mathrm{p}$ & Difference \\
\hline 22. I can use the graded & 1-5 Years & 60 & 55.18 & & & & \\
\hline scoring key effectively in & 6-10 Years & 41 & 47.63 & 4.471 & 2 & .098 & \\
\hline performance evaluation. & 11 Year and Above & 22 & 41.62 & & & & \\
\hline \multirow{3}{*}{$\begin{array}{l}\text { 23. I have enough information } \\
\text { about the grade scoring key }\end{array}$} & 1-5 Years & 60 & 51.25 & & & & \\
\hline & 6-10 Years & 41 & 53.14 & .106 & 2 & .180 & \\
\hline & 11 Year and Above & 22 & 50.96 & & & & \\
\hline \multirow{3}{*}{$\begin{array}{l}\text { 24. I need the help of a } \\
\text { measurement and evaluation } \\
\text { specialist to prepare a graded } \\
\text { scoring key. }\end{array}$} & 1-5 Years & 60 & 55.76 & & & & \\
\hline & 6-10 Years & 41 & 53.65 & 1.520 & 2 & .175 & \\
\hline & 11 Year and Above & 22 & 52.36 & & & & \\
\hline
\end{tabular}

Kruskal Wallis Test was carried out to test whether the opinions of visual arts teachers with different professional qualifications differ on the self-efficacy items of using alternative assessment tools. In the following items, it was observed that there was a significant difference between the rank averages of the groups; "I can give performance tasks per the students' levels $\left(X^{2}(2)=9.235, \mathrm{p}<.05\right)$ ", "I can give students performance tasks that improve students' higher-order thinking skills, $\left(X^{2}(2)=9.412, \mathrm{p}<.05\right)$ ", "The performance tasks I provide include many skills, $\left(X^{2}(2)=9.815, \mathrm{p}<.05\right)$ ", "I can use the performance evaluation effectively in the classroom / workshop $\left(X^{2}(2)=9.453, \mathrm{p}<.05\right)$ ". According to the results of the Mann Whitney U test conducted to determine which group is in favor of the difference, it is determined that this difference is in favor of teachers with professional experience of 11 years or more in articles 12 and 13 , and in teachers of 1-5 years in articles 15 and 21.

According to the results of the research in which Şahin and Atasoy [38] examined the attitudes of teachers towards alternative assessment methods according to the seniority variable, seniority was not determinant in the attitudes of teachers towards alternative assessment methods. This finding supports the findings obtained in the research. As a result of the research in which Groenendijk, Karpati and Haanstra [39] examined the opinions of teachers about using assessment tools, teachers thought it helped them to structure the curriculum and their feedback conversations. These previous studies in line with the results obtained in the current research.

\section{CONCLUSION}

The main purpose of using alternative assessment-evaluation methods is to measure the skills that cannot be measured with traditional assessment-evaluation methods. The main purpose of using alternative assessment-evaluation methods is to measure the skills that cannot be measured with traditional assessmentevaluation methods. The reason for using alternative assessment-evaluation methods in the classroom is to reveal what students can do, not what they do. Students should demonstrate their skills and perform a meaningful task in the use of such techniques. In short, it is the aim of alternative assessment methods to perform a complex task in accordance with the learning objectives from the student and evaluate it. Typical alternative assessment-evaluation tools are portfolios, project assignments, and some activities that often use rubrics.

Teachers' proficiency levels of using alternative assessment tools did not differ considering the professional seniority variable in 22 items. However, there were significant differences in the four items of the questionnaire. According to this; Visual arts teachers, who have 1 to 5 years of professional experience, have many skills compared to teachers with 6 years or more of professional experience, according to the teachers with professional experience between 10 years, it was concluded that their performance tasks cover many skills and that they can use performance evaluation effectively in the classroom/workshop. This results in light of 1 and 5 years of professional experience with teachers KPSS test is necessary to start the profession (examination performed to become teachers in Turkey) because they internalize recently on assessment issues in the preparation process in the 15th and 21 st substance caused them to have seen them more than enough can. In the light of these results, the following suggestions can be made. Teacher training resources should be reconsidered in Turkey. Necessary applications should be increased in teacher training undergraduate programs. Prepare suitable environments for teachers to perform the necessary applications in their professional service courses. Assessment and assessment experts to be employed by teachers should be appointed when necessary. 


\section{REFERENCES}

[1] Eisner E., Educating artistic vision, Macmillon, New York, 1997.

[2] Mamur N., Anadolu güzel sanatlar lisesi resim bölümü öğrencilerinin sanatsal yeterliliğini ölçme ve değerlendirmede EGD’nin (portfolyo) rolü, Yayımlanmamış Doktora Tezi, Gazi Üniversitesi, Eğitim Bilimleri Enstitüsü. Ankara, 2009.

[3] Walker J., "Process portfolios as a means for formative and summative evaluation of student work in the visual arts," The Annual Meeting of the Mid-Western Educational Research Association. Chicago, 1998.

[4] Mohamed R. and Lebar O., "Authentic assessment in assessing higher order thinking skills," International Journal of Academic Research in Business and Social Sciences, vol. 7, no. 2, pp. 466-476, 2017.

[5] Başol G., Eğitimde ölçme ve değerlendirme, Ankara: Pegem Yayıncılık, 2019.

[6] Ling M. K., "The use of academic portfolio in the learning and assessment of physicsstudents from a Singapore Private College," International Journal of Assessment Tools in Education, vol. 3, no. 2, pp. 151-160, 2016.

[7] Herman J.L., Klein D.C., and Wakai S.T., "American students' perspectives on alternative assessment: Do they know it's different?" Assessment in Education, vol. 4, no. 3, pp. 339-351, 1997.

[8] Llewellyn D., Inquiry within: implementing inquiry-based science standards, California: Corwinn Press, 2002.

[9] Demir M., Tananis C. A., and Başboğaoğlu U., "Comparative investigation of alternative assessment methods used in Turkey and United States elementary 4th grade mathematics curriculum," International Journal of Educational Administration and Policy Studies, vol. 10, no. 7, pp. 72-82, 2018.

[10] Ozan C., "Authentic assessment increased academic achievement and attitude towards the educational measurement of prospective teachers," International Journal of Evaluation and Research in Education (IJERE), vol. 8, no. 2, pp. 299-312, 2019.

[11] Açıkgöz K., Aktif öğrenme, İzmir: Eğitim Dünyası Yayınları, 2002.

[12] Armstrong C., Designing assessment in art, Reston: NAEA, 1994.

[13] Beattie D. K., "Creativity in art: The feasibility of assessing currentconceptions in the school context, assessment in education," Principles, Policy \& Practice, vol. 7, no. 2, pp. 175-192, 2000.

[14] Tekin H., Eğitimde ölçme ve değerlendirme, Ankara: Yargı Kitap ve Yayınevi, 2019.

[15] Gill D. and Lucas D., "Using alternative assessment in business and foreign language classes," Journal of International Education Research, vol. 9, no. 4, pp. 359-370, 2013.

[16] Sezer S., "Öğrencinin akademik başarısının belirlenmesinde tamamlayıcı değerlendirme aracı olarak rubrik kullanımı üzerinde bir araştırma," Pamukkale Üniversitesi Ĕgitim Fakültesi Dergisi, vol. 18, no. 1, pp. 61-69, 2005.

[17] Er Ö., Fen ve teknoloji dersi 7. sinıf işık ünitesinde alternatif değerlendirme yaklaşımları temelli ögretimin ögrencilerin akademik başarıları ve tutumları üzerine etkisi, (Unpublished doctoral dissertation). Manisa Celal Bayar Üniversitesi, Manisa, 2018.

[18] Başoğlu S., Klasik ve teknoloji destekli tanılayıcı dallanmış ăgaç tekniğinin öğrencilerin akademik başarılarına, kavram yanılgılarına ve bilişsel yüklerine etkisi, (Unpublished doctoral dissertation). Ordu Üniversitesi, Ordu, 2017.

[19] Manuela R. R. and Jesus G. A. M., "University students' perceptions of electronic rubric-based assessment," Digital Education Review, vol. 30, pp. 220-233, 2016.

[20] Maimouna Al-R and Salma Al-H, "Alternative assessment as Perceived by EFL Teachers," IUP Journal of English Studies, vol. 11, no. 3, pp, 88-101. 2016.

[21] Sewagen A. A. and Diale M. B., Authentic assessment as a tool to enhance student learning in a higher education institution: implication for student competency, (Edt. Elena Railean), Practical Implementation of Assessment Activities for Deep Learning, pp. 256-271. USA: IGI Global Reference Books, 2020.

[22] Gelbal S. and ve Kelecioğlu H., "Öğretmenlerin ölçme ve değerlendirme yöntemleri hakkındaki yeterlik algıları ve karşılaş̧tıkları sorunlar," Hacettepe Üniversitesi, Eğitim Fakültesi Dergisi, vol. 33, pp. 135-145, 2007.

[23] Yapıc1 M. and ve Demirdelen C., "İlköğretim 4. sınıf programına ilişkin öğretmen görüşleri," İlkögrretim Online, vol. 6, no. 2, pp. 204-212, 2007.

[24] Mojavezi A. and Tamiz M.P., "The impact of teacher self-efficacy on the student's motivation and achievement," Theory and Practice in Language Studies, vol. 2, no. 3, pp. 483-491, 2012.

[25] Dilmaç O., The competences of visual arts teachers in using performance evaluation methods: The case of Turkey. A. Karpati and E. Gaul. (Eds.), from child art to visual language of youth. pp. 101-116. UK: Intellect, the University of Chicago Press, 2013.

[26] Baker E.L., "What probably works in alternative assessment, cresst report, national center for research on evaluation, standards, and student testing," 2010. [Online] Available: http://files.eric.ed.gov/fulltext/ED512658.pdf

[27] Huff S., "Teachers' Perceptions of the Teacher Portfolio Process," Doctoral Dissertation, New York: State University of New York at Buffalo, 2006. [Online] Available from: http://proquest.umi.com/ pqdlink? Ver=1\&Exp=05232014\&FMT=7\&DID=1126788031\&RQT =309\&attempt $=1 \& \mathrm{cfc}=1$

[28] Duran M., Mıhladız G., ve Ballıel B., "İlköğretim öğretmenlerinin alternatif değerlendirme yöntemlerine yönelik yeterlik düzeyleri," Mehmet Akif Ersoy Üniversitesi Eğitim Bilimleri Enstitüsü Dergisi, vol. 2, no. 2, pp. 26-37, 2014.

[29] Güneş T., Dilek N. Ş., Hoplan M., Çelikoğlu M., and ve Demir E. S., "Öğretmenlerin alternatif değerlendirme konusundaki görüşleri ve yaptıkları uygulamalar," International Conference on New Trends in Education and Their Implications, 11-13 Kasım. Antalya, 2010.

[30] İzci E., Göktaş Ö., and Şad S. N., "Öğretmen adaylarının alternatif ölçme değerlendirmeye ilişkin görüşleri ve yeterlilik algıları," Journal of Kirsehir Education Faculty, vol. 15, no. 2, pp. 37-57, 2014. 
[31] Kilmen S. and ve Kösteroğlu İ., "Examination of teachers' perceptions towards alternative assessment approaches with cha1d analysis," Elementary Education Online, vol. 16, no. 1, pp. 256-273, 2017.

[32] Oluk Turan N. and Ekmekci G., "Comparıson of alternatıve assessment techniques with traditional techniques 1n termsof measurement of student success," Journal of Research in Education and Society, vol. 4, no. 2, pp. 172-199, 2017.

[33] Oliver E., "Alternative assessment to enhance theological education," HTS Teologiese Studies/Theological Studies, vol. 71, no. 3, pp. 1-10, 2015.

[34] Ozan C., "The effect of authentic assessment on academic achievement and attitude towards educational measurement and opinions of prospective teachers," International Journal of Evaluation and Research in Education (IJERE), vol. 8, no. 2, pp. 299-312, 2019.

[35] Mamur N., "Görsel sanatlar eğitiminde ölçme ve değerlendirme," Pamukkale Üniversitesi Ĕ̆itim Fakültesi Dergisi, vol. 28, no. 2, pp. 175-188, 2010.

[36] Yurdakul B., "Yapılandırmacı öğrenme yaklaşımı öğrenenlerin problem çözme becerilerine, bilişötesi farkındalık ve derse yönelik tutum düzeylerine etkisi ile öğrenme sürecine katkısı," Yayımlanmamış Doktora Tezi, Hacettepe Üniversitesi, Ë̆itim Bilimleri Enstitüsü. Ankara, 2004.

[37] Karamustafaoğlu S., Çağlak A., and ve Meşeci B., "Alternatif ölçme değerlendirme araçlarına ilişkin sınıf ögretmenlerinin öz yeterlilikleri," Amasya Üniversitesi Eğitim Fakültesi Dergisi, vol. 1, no. 2, pp. 167-179, 2012.

[38] Şahin M. and Atasoy E., "Sosyal bilgiler öğretmenlerinin alternatif ölçme-değerlendirme yöntemlerine yönelik tutumlarının değerlendirilmesi," Uşak Üniversitesi Eğitim Araştırmaları Dergisi, vol. 4, no. 1, pp. 18-33, 2018.

[39] Groenendijk T., Karpati A., and Haanstra F., "Self-Assessment in Art Education Through a Visual Rubric," International Journal of Art \& Design Education, vol. 1, no. 2, pp. 1-23, 2019. 